\title{
Håndværk og visioner: designfaglighed på humaniora
}

\author{
Francesco Caviglia, lektor i italiensk, Aarhus Universitet. \\ Christian Dalsgaard, lektor, Center for Undervisningsudvikling og Digitale Medier, \\ Aarhus Universitet.
}

Palle Nørgaard, ph.d.-stipendiat, Institut for Astetik og Kommunikation, Aarhus Universitet.

\section{Reviewet artikel}

\begin{abstract}
Formålet med artiklen er at fremlægge og diskutere erfaringer med, hoordan der kan etableres en designfagstradition i universitetsundervisningen på humaniora, hvor håndværk og vision kan forenes. I artiklen diskuteres underviserens udfordringer med at flytte den humaniorastuderende fra analyse til design, at tage afsæet $i$ praksis, og at forstå projektarbejde $i$ et spændingsfelt mellem vision og håndværk. Der reflekteres endvidere over underviserens mulighed for at klarlægge undervisningens faglige og forskningsmæssige forankring. Artiklens omdrejningspunkt består $i$ en diskussion af spændingsfeltet mellem designfag og videnskabsfag. Udgangspunktet for diskussionen er forfatternes undervisning $i$ to kurser - Kulturformidling og Learning and teaching with digital media - som blev gennemført på Arts, Aarhus Universitet, i perioden 2011-2014.
\end{abstract}

\section{Studerende efterspørger håndværk og visioner}

I et keynote-oplæg på DUN 2014-konferencen påpegede fysikstuderende Anine Borger (KU), at god undervisning på universitetet skulle tilbyde en balance mellem håndværk og visioner. Denne formulering finder vi oplagt som udgangspunkt for at udvikle designbaserede fag på humaniora. Formålet med artiklen er således at diskutere og fremlægge erfaringer med, hvordan der kan etableres en designfagstradition i universitetsundervisningen, hvor håndværk og vision kan forenes. I artiklen fremlægges erfaringer med konsekvenserne af en designbaseret tilgang til undervisningen. Artiklen sætter fokus på følgende perspektiver på designbaseret undervisning: 1) rammesætning af fagets identitet, 2) undervisning på designfag, og 3) det skriftlige arbejde på et designfag.

Disse tre perspektiver diskuteres med udgangspunkt i erfaringer fra to kurser - Kulturformidling og Learning and teaching with digital media - som forfatterne af artiklen underviser i på Arts Fakultetet ved Aarhus Universitet (herefter AU). 
Artiklen indledes med en beskrivelse af, hvad der karakteriserer designfag, og hvad der adskiller dem fra videnskabsfag. Efter en kort beskrivelse af de to kurser og deres ramme diskuteres, hvilke udfordringer underviserne har mødt i forsøget på at fremme en forståelse for en "designfaglighed".

\section{Designfag vs. videnskabsfag}

Videnskabsfag er discipliner, hvis primære formål er at finde ud af og undervise i, hvordan tingene er, og hvordan de virker (Simon, 1988), hvilket typisk er tilfældet hos natur- og socialvidenskab. I designfag arbejder man derimod med henblik på at "devise courses of action aimed at changing existing situations into preferred ones" (ibid.:67): ingeniører og arkitekter, men også forretningsfolk, læger og lærere, kunne således ifølge Herbert Simon betegnes som designere.

Uddannelsen på et designfag kræver en tilgang, som er forskellig fra videnskabsfag, og som ifølge Schön $(1983 ; 1987)$ fokuserer på den såkaldte reflekterende praksis som udgangspunkt for udvikling af ekspertise. Sådan defineres for eksempel målet i 2014-studieordningen for uddannelsen i Teoretisk Pædagogikum for danske gymnasielærere:

"Målet er at uddanne reflekterende praktikere, som er i stand til at forstå og udvikle egen undervisning gennem inddragelse af forskning og teorier om relevante emner og omsætte deres viden i tilrettelæggelse og gennemførelse af det praktiske forløb." (SDU, 2014 - vores fremhævelse).

Richard Sennett (2009) tilbyder et læringsperspektiv på designfagligheden. Med øje for stoltheden og det opslugende engagement forbundet med skabelsesprocesser peger Sennett (ibid.) på, hvordan den dygtige håndværker ønsker at gøre arbejdet godt, for arbejdets egen skyld. En sådan håndværker "fører en dialog mellem konkret praksis og sin tænkning. Denne dialog udvikler sig til underbyggende vaner, og disse vaner etablerer en rytme mellem problemløsning og problemafdxkning" (Sennett, 2009:19). Ligesom i Schöns reflekterende praksis $(1983 ; 1987)$ består håndværksmæssigheden ifølge Sennett i "evnerne til at lokalisere, til at stille spørgsmål, og til at åbne op [hvor] Den forste indebærer, at man gør en ting, den anden at man reflekterer over dens egenskaber, den tredje at man udfolder dens betydning" (Sennett, 2009:278). Af særlig interesse er den gevinst, som Sennett kan lade os ane i designprocessen i form af dens potentielt frigørende karakter. Frigørende, fordi den studerende kan måle sig selv på det efterladte resultat, der, modsat en endeløs psykologisk selvbearbejdning, her findes uden for ham selv i det færdige produkts virkelige verden. Arbejdet kan for den reflekterende håndværker i dette perspektiv blive målet i sig selv: Fordi han kan spejle og måle sig selv. En sådan omverdensvendt, frigørende karakter ved (hånd)værkets "virkelige" målestok kan medtænkes i en designfaglighed. Sennetts perspektiv fokuserer således på designfaglighedens tekniske processers intime forbindelse med produktets ud- 
tryk: "[Teknik] kan være sjælløs. Men det er ikke sådan, at folk med øvede hænder ser det" (ibid.:155). " Håndværket, forstået som det særlige og berigende engagement i skabelsesproces og produkt, synliggør forbindelseslinjerne mellem mål og midler, arbejdsproces og resultat.

Det er imidlertid vigtigt at understrege, at et fokus på design frem for på viden historisk set afspejler en konflikt inden for universitetsverden, hvor designdimensionen blev tildelt en lavere akademisk status end erkendelsesdimensionen i videnskabsfagene (Simon, 1996:111-114). Hertil kan det siges, at det er et åbent spørgsmål, hvorvidt løsninger på komplekse designproblemer - fx i tilrettelæggelse af undervisning primært skal anses som omsætning af teorier og designprincipper til praksis, eller om de skal forstås som resultater af en refleksiv samtale i en lokal situation (se en diskussion af de to perspektiver i Chua, 2011 og Holmberg, 2014).

\section{De to kurser}

De to kurser, der anvendes som eksempler i artiklen, tilhører begge et designfagligt paradigme. Det ene fag - Kulturformidling som case-studium (herefter GKI-formidling) - er et modul inden for tredje og sidste semester af tilvalgsuddannelsen i Globalisering og kulturel identitet, som har været udbudt siden efteråret 2011 til studerende på Arts ved AU. ${ }^{1}$ De cirka 30 studerende, som fra foråret 2012 hvert år har tilmeldt sig kurset, har forskellige baggrunde, herunder i sprogfagene, Historie, Medievidenskab og Antropologi. Disse studerende fravælger implicit en karriere som gymnasielærere, idet deres tilvalg ikke findes som fag på gymnasiet. Det andet fag Learning and teaching with digital media (herefter LTDM) - har været udbudt fra foråret 2013 til grupper af 10 til 28 kandidatstuderende - også uden for Arts - som vælger en underviserprofil. Kurset besøges dog mest af Arts-studerende, hvor cirka en tredjedel har været udvekslingsstuderende. Undervisernes faglige baggrund er henholdsvis IT og læring (FC og CD) og Kulturanalyse og Virksomhedskommunikation (PN). De to kurser er udviklet efter principper i "educational design research" (van den Akker, Gravemeijer, McKenney \& Nieveen, 2006; McKenney \& Reeves, 2013), og kursernes design er evalueret og revideret efter hver afholdelse.

De to kurser havde til fælles, at de i stort omfang byggede på fagligheder, som de studerende tidligere har erhvervet sig i deres uddannelse, og at cirka en tredjedel af kurserne bestod i et selvvalgt projektbaseret arbejde, hvor de studerende blev sat til at udvikle henholdsvis et formidlingsprojekt og en læringsenhed (i form af et undervisningsforløb eller lignende).

\footnotetext{
${ }^{1}$ Se fagbeskrivelsen på http://tilvalg.au.dk/globalisering-og-kulturel-identitet/, set 15-01-2015.
} 
En forskel på de to kurser var de studerendes evne til at identificere kurset med en professionel og erhvervsmæssig identitet. LTDM-studerende kunne uden problemer relatere undervisningen til en identitet som gymnasielærere, mens de GKIstuderendes rolle i erhvervslivet som kulturformidler - eller kulturaktør - i begyndelsen var diffus og uklar for de studerende. Dog blev de studerende i stigende grad engagerede i takt med, at deres eksamensprojekter begyndte at tage form. Projekterne have eksempelvis form af websider med integration af video og lydfiler baseret på egne interviews og optagelser, interviewbaserede dokumentarfilm og skitser til udvikling af mobile apps. Det stigende engagement kunne således tolkes som om, at den specifikke indholdsmæssige og kontekstspecifikke idé tydeliggjorde projektets realisme i erhvervslivet.

Diskussionerne i artiklen baserer sig først og fremmest på undervisernes deltagelse i de to ovennævnte kurser og undervisernes erfaringer med og løbende refleksion over problemstillinger i relation til undervisning i disse fag som designfag. Deltagelsen i kurserne involverede både tilrettelæggelse og afvikling, herunder vejledning af studerende. GKI-formidling kørte tre gange med henholdsvis 13, 22 og 29 studerende (64 i alt), og LTDM kørte ligeledes tre gange med henholdsvis 20, 23 og 10 studerende (53 i alt). Desuden inddrages de studerendes mundtlige og skriftlige eksamen samt kursusevalueringerne, der består af skriftlige og mundtlige midtvejsevalueringer og afsluttende evalueringer. Med afsæt i erfaringerne fra kurserne diskuterer artiklen nedenfor, 1) hvordan underviserne har arbejdet med at rammesætte fagets identitet, 2) undervisning og undervisningsformer på kurserne som designfag og 3) rollen af og formen på det skriftlige arbejde på designfagene.

\section{Rammesætning af fagets identitet}

Af samtaler med de studerende og af kursernes evalueringer har det fremgået, at begge kurser har været opfattet af de studerendes som anderledes i forhold til deres tidligere erfaringer på universitetet. På de forskellige årgange har vi som undervisere observeret et mønster, hvor de studerende har været nysgerrige fra starten, efterfulgt af en vis forvirring om kursets formål og identitet, og siden efterfulgt af voksende interesse og indsats fra de studerende side så snart de begyndte at se, hvordan deres eksamensprojekter kunne udformes.

I dette afsnit diskuteres, hvordan underviserne forsøgte at rammesætte "det anderledes" og italesætte den faglige forskel. Projekterne i begge kurser havde som formål at iværksætte processer, som relaterede sig til et tema om læring. Det var eksplicit i LTDM, hvor formålet med de studerendes læringsenheder netop var at designe til læring, mens det var implicit i GKI-formidling, hvor de studerende skulle være bevidste om den læringsdimension, der var indbygget i deres formidlingsprodukter. Det var vores opfattelse ud fra samtaler med de studerende, at mange i begyndelsen primært anså formidling og undervisning som overførsel af eksisterende viden. Det- 
te gav sig blandt andet udtryk ved, at det viste sig at være vanskeligt at forklare de studerende, hvad vi mente med idéen om, at undervisernes og formidlernes kompetencer først og fremmest bestod i at kunne iværksætte processer.

Fra undervisningens begyndelse gjorde vi eksplicit en pointe ud af, at kursets struktur og eksamensform opfordrer til, at man overfører teori fra de studerendes uddannelsesmæssige baggrund. Alligevel havde de studerende vanskeligt ved at forbinde deres faglighed fra de foregående år på universitetet med idéen om at designe lærings- og formidlingsaktiviteter. Disse vanskeligheder skyldtes imidlertid ikke, at de studerende havde en naiv opfattelse af læring som "ting som skal puttes ind i hove-

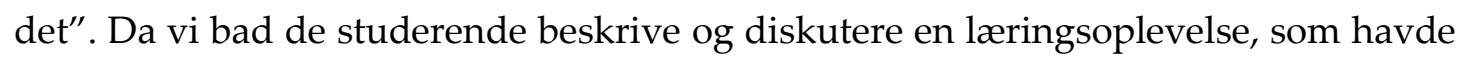
været vigtig eller spændende for dem, var de udmærket i stand til at reflektere over læringsprocesser med udgangspunktet $\mathrm{i}$ individets interaktion med den sociale og materielle kontekst. Men formidlingsprocessen (GKI) og læringsprocessen (LTDM) forblev tilsyneladende sekundære processer, der blot skulle videreformidle de indsigter, man havde opnået gennem analyse og anvendt teori.

Hvordan og hvorvidt lykkedes vi i at overbevise de studerende om, at undervisning eller formidling først og fremmest består i at designe og iværksætte processer? I den første udgave af GKI-formidling overlod vi primært dette spørgsmål til vejledning af eksamensprojekterne. Vi brugte primært konfrontationstimerne i den første del af kurset til at demonstrere og diskutere teorier og gode eksempler, med den tanke inspireret af Schöns idé om 'reflection-in-action' (1987:22-40) - at gruppecoaching og fælles vejledning til eksamensprojekterne i den anden del af kurset tilbød de bedste muligheder for at synliggøre behovet for at reflektere over processerne inden for den konkrete ramme af formidlingsaktioner. Resultaterne var blandede. Både studerende og undervisere blev til sidst tilfredse med projekterne, men i midtvejsevalueringen af kurset kom kritikken af, at kursets faglige identitet ikke var klar nok fra begyndelsen. At vi undervisere ikke altid nåede at synliggøre fagets identitet blev bekræftet, da en GKI-studerende, få dage efter en succesfuld eksamen, kommenterede ved en mundtlig slutevaluering, at hun helst i forvejen ville have fået at vide, hvad hun skulle formidle. Dette udsagn demonstrerer, at 1) den studerende stadigvæk anså formidling primært som overførsel af viden og som om et produkt (i hendes projekt flyers og stedbundet fortælling) og 2) at hun ikke havde set relevansen af den proces, som havde ført til valg af emne og tilgang i hendes projekt. Med andre ord havde den studerende opfyldt kravene i kurset uden at forstå eller værdsætte det kreative og procesorienterede element i kursets faglighed. Det tolkede vi som tegn på, at vi skulle ændre noget ved måden hvorpå, vi synliggjorde kursets faglige identitet. 
Fra efteråret 2013 valgte vi derfor eksplicit at definere både LTDM og GKIformidling som designfag og forklare, hvordan et designfag adskiller sig fra videnskabsfag, og hvordan de to typer af fagligheder kan være i konflikt, både epistemologisk og i kampen om akademisk anerkendelse. Forklaringen om, at kursernes faglighed hørte til et designparadigme, gjorde det tilsyneladende nemmere for de studerende at acceptere, at denne undervisning var anderledes end det, de havde været vant til på deres tidligere uddannelser.

\section{Undervisning på designfag}

Jo tydeligere vi blev til at forklare kursernes forskellighed fra øvrige kurser, jo tydeligere blev det samtidig, at undervisningsformen i højere grad skulle afspejle kursernes anvendelsesorientering. De studerende på de to kurser har som nævnt arbejdet aktivt med design af henholdsvis en læringsenhed og et formidlingsprojekt. Undervisningsformen på de to kurser skulle understøtte de studerendes arbejde med dette designorienterede projekt.

Som beskrevet tidligere er målet med designbaserede fag at engagere de studerende som reflekterende praktikere. Schöns begreb om 'refleksiv praksis' (reflective practicum, Schön, 1987) udgør en anvendelig ramme til at beskrive undervisningsformen på et designbaseret kursus. Hensigten med et reflective practicum er at bygge bro mellem den fagorienterede universitetsverden og konkrete praksisser. Et practicum skal etablere en autentisk ramme om et projekt, men skal samtidig repræsentere en simuleret verden, der afspejler en virkelig praksis. Schöns idé om et practicum er inspireret af Dewey (1907), der argumenterer for at nedbryde grænserne mellem uddannelsesinstitutioner og det omkringliggende samfund. Af disse betragtninger om undervisningen som en form for eksperimentelle praksisser kan man uddrage, at studerendes arbejde skal tage udgangspunkt i empiriske problemer (Dalsgaard, 2007). Empiriske problemer kan ifølge Dalsgaard (2007) have form af mål, ønsker, visioner, idéer og lignende, der målretter den studerendes blik mod at anvende og forme praksis med et bestemt formål. På de to kurser har vi forsøgt at tage afsæt i empiriske problemer og idéer, der rækker ud i samfundet og ikke blot udgør videnskabelige eller teoretiske problemstillinger. Konsekvensen er, at praksis - i form af empiriske problemer og idéer - bliver sat før teori.

Fra begyndelsen af kurserne forsøgte vi at sætte gang i de studerendes praktiske arbejde. Imidlertid lykkedes det ikke for kursusforløbene i første gennemløb at etablere de studerendes projektarbejde tidligt i processen. I stedet kom den teoretiske dimension og forelæsningerne til at dominere mere, end hensigten havde været, og det var først hen mod slutningen af kursusforløbene, at de studerende arbejdede fokuseret med deres projekter. Her må vi som undervisere erkende, at vi også hang fast i en tankegang fra videnskabsfag, idet vi kom til at fokusere for meget på traditionel teorigennemgang. Praksis blev med andre ord ikke sat før teori, idet projekterne ikke blev gjort til centrum for de studerendes aktiviteter. 
I senere gennemløb af kurserne har vi derfor revideret kursusforløbene med henblik på at etablere de studerendes designbaserede projektarbejde helt fra begyndelsen. Oprindeligt havde vi taget afsæt i et empirisk problem, men vi havde samtidig tænkt teori først på den måde, at de studerende først skulle have teoretiske og begrebslige forudsætninger, før de kunne begynde at udvikle og designe. I senere gennemløb har vi taget konsekvensen af en designbaseret tilgang og byttet helt om på teori og praksis således, at de studerende i den første fase arbejder på deres praktiske projekt. Når de studerende har et første udkast eller en skitse til deres projekt, bliver forskellige teorier introduceret med henblik på, at de studerende skal reflektere over og revidere deres projekt på baggrund af teorierne.

Endnu en central udfordring ved at etablere designbaserede undervisningsformer er ændrede roller for både undervisere og studerende. Kursusforløbene på de to fag baserer sig på en høj grad af studenteraktivering i den betydning, at de studerende ideelt set selv skal tage styring med deres projektarbejde. Projektet - i modsætning til lektioner - skal rammesætte de studerendes aktiviteter på kurset. Ifølge Schön (1987:181) bliver det en central rolle for underviseren at kunne facilitere refleksionsprocessen ved at indgå som deltager, vejleder og coach, der demonstrerer praksis, giver råd og stiller kritiske spørgsmål, mens den studerendes rolle bliver den reflekterende praktiker.

På de to kurser er vi ikke fuldt ud lykkedes i at ændre de traditionelle studenter- og underviserroller til henholdsvis vejleder/coach og reflekterende praktikere. Det var vores klare opfattelse, at de studerende i de første gennemløb af kurserne havde en forventning om, at underviserne gennemgik stoffet og på den måde leverede kursets indhold på de ugentlige lektioner. Dog er det vores erfaring, at vi i de seneste gennemløb af kurserne har fået rokket ved de traditionelle roller, og at vi har fået flyttet den traditionelle rolle som underviser mere i retningen af vejleder og ligeledes er lykkedes i at engagere de studerende mere i deres projekter. Dette har vi opnået ved at bruge mere tid på at rammesætte de studerendes selvstændige arbejde og gøre det mere synligt både mellem og på kursusgangene. Eksempelvis har vi opstillet milepæle for de studerendes arbejde med henblik på at fokusere deres projektarbejde. Som et væsentligt element er mængden af vejledning forøget betydeligt (for en detaljeret gennemgang af projektarbejdet se Hagedorn-Rasmussen \& Mac, 2013). Disse tiltag har været medvirkende til, at projektarbejdet har flyttet sig nærmere centrum for de studerendes arbejde. Vi ser dog stadig i evalueringerne, at de studerende efterspørger mere teori og flere forelæsninger, der gennemgår teoretisk stof. 


\section{Det skriftlige arbejde på et designfag}

Begge kurser inkluderede i eksamensforløbet - ud over et 'produkt' (læringsenhed eller formidlingsprodukt/-proces) - en kort skriftlig redegørelse (2-3 sider) for de teoretiske overvejelser omkring udformning af formidlingsprojektet. Refleksion om projektet og produktet var desuden en del af den afsluttende mundtlige eksamen. Den 'skriftlige redegørelse' havde det tilfælles med den traditionelle universitetsopgave, at den skulle indeholde henvisninger til kilderne. Til gengæld var teksten kortere og dens formål inden for eksamensforløbet var at synliggøre projektets inspirationskilder og forklare nogle valg i projektets design; teksten var med andre ord en introduktion og et tillæg til projektet, og forventedes at fremme og synliggøre den refleksive dimension i projektarbejdet. I begge vores kurser udgjorde det skriftlige arbejde omkring $1 / 3$ af bedømmelsesgrundlag.

Denne korte tekst blev en udfordring for de studerende, dels fordi de tit havde svært ved at forbinde deres refleksion over projektet med deres opfattelse af, hvad teori er, dels fordi de ikke kunne relatere til et passende tekstforbillede fra deres tidligere erfaringer med universitetsopgaver. Det er vores erfaring, at danske studerende på humaniora lærer at strukturere en opgave, som begynder med en problemstilling og indeholder teori, analyse og syntese (se fx Reitan \& Togeby, 2001:9-13). Denne struktur - som afspejler den typiske argumentationsform på en videnskabelig artikel - har som formål at producere ny viden og er oplagt til videnskabsfag, hvor det skriftlige produkt er det mest synlige eller det eneste synlige element $i$ arbejdsprocessen. I disse opgaver er teorien typisk alfa og omega i arbejdsprocessen, i takt med, at studerende skal være i stand til at anvende fagspecifikke teorier og metoder til at producere selvstændig erkendelse (Studiemetro, u.d.). På designfag lærer man i stedet ikke primært ved at tilegne sig og derefter anvende en teori, men typisk - som diskuteret ovenfor - med udgangspunkt i reflekterende praksis, som er indbygget i sted- og situationsbestemte artefakter, processer, løsninger (Schön, 1987; Coyne, 2004; Sennett, 2009; Holmberg, 2014).

I undervisning og vejledning forklarede vi, at den skriftlige opgave skulle beskrive de studerendes valg i udformningen af deres projekt; vi foreslog en tjekliste af elementer - med særlig fokus på projektets inspirationskilder - som vi forventede at finde i deres opgave. Samtidig insisterede vi på, at tekstens struktur skulle skræddersys til det enkelte projekt. I forbindelse med vejledning fremgik det imidlertid, at nogle studerende stadigvæk var bekymrede eller forvirrede, på trods af deres gode projekter, fordi de ikke vidste - med deres ord - "hvilke teorier de skulle bruge". Forskellige skriftlige arbejder afspejlede denne bekymring. Da vi læste de skriftlige opgaver i den første udgave af kurset i GKI-formidling, fik vi således indtrykket af, at nogle af de teoretiske henvisninger havde som primært formål at demonstrere over for underviserne, at de studerende havde læst teksterne fra pensum i de forudgåen- 
de moduler af GKI-forløbet. Med andre ord var de teoretiske overvejelser i nogle tilfælde en eftertanke til projektet, eller de studerende "snakkede teorien efter munden", som en studerende selv kommenterede det. I den mundtlige diskussion havde de studerende dog været i stand til at forklare, forsvare og reflektere over deres projekter.

Problemet med den skriftlige opgave på GKI-kurset tillagde vi (FC og PN) en uklarhed fra vores side om tekstens formål kombineret med en tilsyneladende tilbøjelighed blandt de studerende til at overføre deres erfaringer fra tidligere skriftlige opgaver med en videnskabsfaglig tilgang til tekstproduktion i forbindelse med et designfagligt projektarbejde. Det fremgik af eksamensopgaverne, at de studerende fandt det vanskeligt at forstå eller genkende den skriftlige redegørelses akademiske genre. Denne problematik tillagde vi især en usikkerhed blandt studerende på, hvordan de skulle definere teoriens rolle i deres projekter. Med andre ord skulle vi arbejde videre på to fronter: 1) at forbedre definitionen, genren og formålet med opgaven; 2) at finde tekster og best practice-eksempler, som de studerende direkte kunne relatere deres projekter til.

Vi besluttede derfor - i de efterfølgende udgaver af kurset - at flytte fokus fra arbejdets form til dets funktion, og vi foreslog, at de studerendes skriftlige arbejde kunne sammenlignes med tekster, som fx rapporter fra tænketanke, projektansøgninger eller vejledninger til fondansøgninger, som primært bruges til at tage initiativer og informerede beslutninger. I kursets sidste udgave (foråret 2014) stillede vi det konkrete forslag, at projekterne skulle indrammes som et projektinitiativ i anledning af udnævnelsen af Aarhus som europæisk kulturhovedstad i 2017. Den tematiske ramme var og er her Rethink 2017.2 Dermed blev det naturligt, at de fleste arbejdsgrupper valgte at skrive deres opgaver som om, de var en del af en ansøgning om midler til udførelse af deres projekt. Underviserne kom derefter til at fungere som medlemmer af et bedømmelsesudvalg for ansøgninger.

Den skriftlige opgave i LTDM-kurserne var lidt mindre problematisk, idet underviserne fra starten kunne foreslå en skabelon for udvikling af læringsenheder (baseret på Wiggins og McTighe, 2005 og McTighe og Wiggins, 2013). Imidlertid oplevede vi lejlighedsvis også i dette kursus, at referencerne til teori ikke var tilstrækkeligt integreret i projektets design og virkede som en eftertanke. Fra foråret 2014 adopterede vi derfor også en fiktiv ansøgningslignende ramme for den skriftlige og mundtlige eksamen, hvor de studerende skulle overbevise skolens pædagogiske leder (spillet af FC og CD) om at det ville være en god idé for skolen at afprøve og evt. adoptere de studerendes læringsenhed.

${ }^{2}$ http://www.aarhus2017.dk/hvad er rethink, set 15-01-2015. 
Den reviderede ramme og formål med det skriftlige arbejde samt diskussioner og vejledningssessioner om valget af formidlings- og undervisningsformer hjalp med at få mere sammenhængende skriftlige opgaver, som støttede den ønskede refleksion over praksis. Samtidigt oplevede vi også, at det var svært at finde tekster, som direkte hjalp med at reflektere over eksempler på best practice, og dermed også over de studerendes egne projekter. Inspirationskilderne til projekterne var nemlig først og fremmest eksempler, mens de studerende brugte de teoretiske tekster primært til at hente analytiske begreber til at beskrive eksemplerne. Eksemplerne var dog typisk sparsomme eller ikke dokumenterede, mens de teoretiske tekster typisk var skrevet med analyse, og ikke design, for øje.

\section{Afsluttende refleksioner: Behov for akademisk anerkendelse af designfaglighed}

Hvilke erfaringer kan vi uddrage af kurser baseret på en designfaglighed til studerende på humaniora? Det har været en stor udfordring at skabe kursusforløb, hvor studerende først og fremmest fokuserer på et projekt orienteret mod praksis og dernæst anvender teori som refleksion over praksissen. Selvom vi primært har mødt motiverede og engagerede studerende, kan vi spore en tendens til, at de studerendes engagement var proportionalt med, at deres projekter var mere eller mindre virkelighedsnære. Nogle af de LTDM-studerendes bedste projekter resulterede i udviklingen af læringsenheder, som var skræddersyede til en bestemt gruppe af elever. Hos de GKI-studerende var de stærkeste projekter formuleret som realistiske ansøgninger til kulturfonde som eksempelvis Aarhus Rethink-2017-programmet.

En central erfaring er, at etablering af designbaserede kursusforløb ikke blot er et spørgsmål om at indføre en ny undervisningsform, men at det samtidigt berører den faglige identitet og selvopfattelse på universitetsuddannelserne. Designfagligheden og anvendelsesorientering i universitetsundervisningen er ikke uproblematisk. Ideelt set burde traditioner inden for videnskabs- og designfagligheder komplementere hinanden, og - som i andre dele af samfundet - i sund konkurrence. I den akademiske verden er forholdet dog ofte konfliktfyldt og kan resultere i en form for magtkamp om ressourcer og anerkendelse mellem teoretisk og praksisorienteret forskning. Ifølge Whitworth og Friedmans kritik af nuværende magtforhold i akademisk publicering (Whitworth \& Friedman, 2009) bliver teorien typisk anset som mere værdifuld end praksis pga. teoriens stringens og tilknytning til den videnskabelige diskurs, mens forskning som tilstræber at være relevant for praksis er nødt til at søge nye veje for at blive synlig.

Introduktionen og styrkelsen af designfagligheden i undervisningen åbner derfor i vores perspektiv også op for en genovervejelse af undervisningens form, det teoretiske indhold og den meriterende bedømmelse af den akademiske tekst. Der findes p.t. 
et ringe incitament for reflekterende praktikere - $\mathrm{i}$ hvert fald på humaniora - til at publicere uden for de gængse akademiske tidsskrifters rammer og ikke mindst formater. For eksempel vil en rapport som Fællesskaber i forandring (Tænketanken Byen 2025, 2014), der i undervisningen har været en øjenåbner og inspirationskilde for vores GKI-studerende, blot tælle på de involverede forskeres publikationsliste som andenrangs "formidlingsarbejde". Ligeledes var det muligvis på grund af det ringe incitament for forskerne til at publicere undervisningspraksisser og -ressourcer, at det i vores LTDM-kursus var svært at finde forbilleder til projekterne, til trods for, at der findes modeller for teoretisk velovervejede 'worked examples' på læringsaktiviteter, som er tænkt til at blive diskuteret, afprøvet og adapteret (eksempelvis i Gee, 2010).

Etableringen af en designfagstradition i universitetsundervisningen griber med andre ord ind i diskussionerne om akademisk anerkendelse af designprocesser og produkter.

Francesco Caviglia er ph.d., lektor i Italiensk på Aarhus Universitet. Han forsker i læring på Humaniora med fokus på literacy og digitale dannelse.

Christian Dalsgaard er cand.mag., ph.d., lektor på Aarhus Universitet på Center for Undervisningsudvikling og Digitale Medier. Han forsker i IT og læring med fokus på internettets læringspotentialer.

Palle Norgaard er ph.d.-stipendiat på Aarhus Universitet på Æstetik og Kommunikation og tidligere ekstern lektor ved Center for Virksomhedskommunikation. Han forsker i kulturel erindring og fortællinger.

\section{Litteratur}

Chua, S. M. J. (2009). Donald Schon, Herbert A Simon and The Sciences of the Artificial. Design Studies, 30(1), s. 60-68.

Coyne, R. (2005). Wicked problems revisited. Design Studies, 26(1), s. 5-17.

Dalsgaard. C. (2007). Åbne læringsressourcer - mod en sociokulturel teori om læringsressourcer. Ph.d.-afhandling. Århus: Institut for Informations- og Medievidenskab, Aarhus Universitet.

Dewey, J. (1907). The School and Society. Chicago: University of Chicago Press.

Gee, J. P. (2010). New Digital Media and Learning as an emerging area and "worked examples" as one way forward. Cambridge, MA: MIT Press.

Hagedorn-Rasmussen, P. \& Mac, A. (red.) (2013). Projektarbejdets kompleksitet: viden, værktøjer og læring. Frederiksberg: Samfundslitteratur.

Holmberg, J. (2014). Studying the process of educational design - revisiting Schön and making a case for reflective design-based research on teachers' 'conversations with situations'. Technology, Pedagogy and Education, 23(3):s. 1-18.

McKenney, S. E. \& Reeves, T. C. (2012). Conducting educational design research. New York, NY: Routledge.

McTighe, J. \& Wiggins, G. P. (2013). Essential Questions: Opening Doors to Student Understanding. Alexandria, VA: Association for Supervision \& Curriculum Development (ASCD). 
Reitan, R. \& Togeby, O. (2001). Skriftlige hjemmeopgaver. Normer og krav. Århus: Institut for Nordisk Sprog og Litteratur, Aarhus Universitet. Online: http://rum1.aarch.dk/uploads/media/krav og_normer til_den skriftlige hjem meopgave.pdf, set 15-01-2015.

Schön, D. A. (1983). The Reflective Practitioner. New York, NY: Basic Books.

Schön, D. A. (1987). Educating the Reflective Practitioner. San Francisco, CA: JosseyBass.

SDU (2014). Studieordning for Uddannelsen i Teoretisk Pædagogikum. Odense: Syddansk Universitet. Online: http://www.sdu.dk/om sdu/institutter centre/ikv/uddannelse/paedagogikum1 Lstudieordning, set 15-01-2015.

Sennett, R. (2009). Håndværkeren. Viborg: Forlaget Hovedland.

Simon, H. A. (1996). The Science of the Artificial. 3. udgave (1. udgave: 1988). Cambridge, MA: MIT Press.

Studiemetro (u.d.). Videnskabelighed i opgaver. Studiemetro, Aarhus Universitet. Online: http://studiemetro.au.dk/krav/videnskabelighed-i-opgaver/, set 15-012015.

Tænketanken Byen 2025 (2014). Fællesskaber i forandring. Ministeriet for by, bolig og landdistrikter. Online: http://www.mbbl.dk/publikationer/faellesskaber-iforandring-taenketanken-byen-2025, set 15-01-2015.

Van den Akker, J., Gravemeijer, K., McKenney, S. \& Nieveen, N. (Eds.) (2006). Educational design research. New York, NY: Routledge.

Whitworth, B. \& Friedman, R. (2009). Reinventing academic publishing online Part I: Rigor, relevance and practice. First Monday, 14: 8, 3 August 2009. Online: http://firstmonday.org/ojs/index.php/fm/article/view/2609/2248, set 28-08-2014.

Wiggins, G. \& McTighe, J. (2005). Understanding by Design (Expanded Second Edition). Alexandria, VA: Association for Supervision \& Curriculum Development (ASCD). 